(C) 2000 Blackwell Wissenschafts-Verlag, Berlin

ISSN 0931-2439

\author{
Department of Animal Science, University of Adelaide, Waite Agricultural Research \\ Institute, Glen Osmond, South Australia, Australia
}

\title{
Heterosis, sex and breed differences in the fatty acid composition of muscle phospholipids in beef cattle
}

\author{
By A. E. O. Malau-Aduli, B. D. Siebert, C. D. K. Bottema \\ and W. S. PITCHFORD
}

\begin{abstract}
Summary
Longissimus dorsi muscle tissue was biopsied between the 12th and 13th ribs of 96 purebred Jersey, purebred Limousin and Jersey $\times$ Limousin crossbred calves at the age of 9-10 months. Fatty acids of the phospholipid fraction were extracted and analysed for sex and breed differences. Heterosis, additive and maternal variances were estimated. All calves grazed pasture in a single management group and were biopsied from the same anatomical site. Steer calves had significantly higher proportions of the $14: 0,14: 1,18: 2,20: 3$ fatty acids and less of the 16-di-methyl-acetal than heifer calves. Significant breed differences were observed: Limousin calves had the highest proportions of 16:0, 24:0 and saturated fatty acids (SFA), whereas Jersey $\times$ Limousin calves had the most 18:0 and elongation index. Dominant effects were evident in the proportions of $16: 0,18: 0$, SFA and elongation index. Additive genetic effects were significant in the proportions of $16: 0,18: 0,18: 1 \mathrm{n}-9$, total SFA and desaturation and elongation indices. Combined maternal and additive effects were significant for long chain polyunsaturated fatty acids $18: 2,20: 3$ and $20: 4$.
\end{abstract}

\section{Introduction}

The role of phospholipids is primarily as constituents of the lipoprotein complexes of muscle and biological cell membranes. They also play a role in growth since they affect animal metabolism and cell anabolic processes (SCOTT and ASHES 1993). In beef semitendinosus, longissimus and triceps brachii muscles, 9 to $14 \%$ of total lipids consists of phospholipids and from 82 to $90 \%$ as neutral lipids (O’KEEFE et al. 1968). Similar proportions of lipids were observed by ROMANS et al. (1974) for Longissimus dorsi muscle: $14 \%$ phospholipids and $82 \%$ triacylglycerols. Up to $20 \%$ of lipids in beef muscle trimmed of depot fat consist of phospholipids (HORNSTEIN et al. 1961), whereas MILLER et al. (1986) reported from $11 \%$ muscle phospholipids in feed-lot steers to $46 \%$ muscle phospholipids in game animals. Thus, phospholipids represent a greater proportion of the total lipids in muscle than they do in adipose tissue (RULE et al. 1995).

In a preliminary report, it was demonstrated that additive, maternal and dominance effects were significant for fatty acids in the triacylglycerol fraction of the bovine adipose tissue (MAlau-Aduli et al. 1998a). It has not yet been established whether fatty acids of the phospholipid fraction of muscle tissues exhibit the same or different phenomenon. The aim of this study was to estimate the genetic effects of heterosis, additive and maternal variances 
as well as investigating sex and breed differences in phospholipid fatty acid composition of L. dorsi muscle from grazing cattle.

\section{Materials and methods}

Longissimus dorsi muscle tissue was biopsied from the area between the 12th and 13th ribs in 96 Jersey, Limousin and reciprocal $F_{1}$ Jersey $\times$ Limousin calves at 9-10 months of age. All the calves grazed pasture and were maintained in a single management group as part of the J.S. Davies Bovine Gene Mapping herd, Martindale, South Australia. Phospholipid fatty acids were extracted, methylated and analysed by gas-liquid chromatography as described by MALAU-ADUli et al. (1998b). Fatty acid retention times were compared with known reference standards for identification of individual C14-C24 fatty acids.

The normalized values of fatty acid percentages were statistically analysed using PROC GLM (SAS 1989). The first model included the fixed effects of sex and breed, and their interaction. Least squares means were computed to test for significant differences between sexes and breeds. The second model for the estimation of heterosis included the fixed effects of sire and dam breeds and their interaction. Sire-breed accounted for additive genetic effect whereas dam-breed estimated combined additive and maternal effects. Heterosis, that is nongenetic effect attributed to dominance, was estimated by the interaction between sire and dam breeds. Thus, heterosis for a given fatty acid was computed as the mean deviation between the crossbred and parental breeds. Similarly, additive genetic effect was computed as the mean deviation between Jersey and Limousin sire breeds, whereas the deviation between the dam breeds respectively, was the combined additive and maternal effects.

\section{Results}

Individual fatty acids (C14-C24) from the Longissimus dorsi muscle biopsied from the area between the 12th and 13th ribs were measured in young Jersey, Limousin and $F_{1}$ Jersey $\times$ Limousin calves. The factors fitted in the model and tests of significance used to analyse the fatty acid data are shown in Table 1.

Sex differences were significant in the proportions of the individual fatty acids, myristate $(14: 0)$, myristoleate $(14: 1), 16$-di-methyl-acetal (16DMA), linoleate $(18: 2)$ and di-homogamma linolenate $(20: 3)$ (Table 1). Steer calves had higher proportions of $14: 0$ (3.7 versus $2.6 \%), 14: 1$ (0.9 versus $0.6 \%), 18: 2$ (11.2 versus $10.7 \%), 20: 3(0.4$ versus $0.1 \%$ ) and less 16DMA (3.4 versus $4.9 \%$ ) than heifer calves (Table 2). However, summations of saturated, mono-unsaturated and polyunsaturated fatty acids, desaturation and elongation indices and ratios did not differ between sexes.

Breed differences were significant in the proportions of palmitate $(16: 0)$, stearate $(18: 0)$ and lignocerate $(24: 0)$. Summations of total saturated (SFA) and polyunsaturated (PUFA) fatty acids, ratios of unsaturated to saturated (USR), polyunsaturated to saturated (PSR) and elongation index significantly differed between the breeds (Table 1).

Limousin calves had the highest proportions of 16:0 (22.6\%), 24:0 (1.6\%) and SFA $(45.8 \%)$, whereas Jersey $\times$ Limousin calves had the highest proportions of 18:0 $(12.4 \%)$ and elongation index $(62.4 \%)$ (Table 3$)$. Sex by breed interaction was a significant source of variation in the proportions of the individual fatty acid 20:4, total SFA, PSR and elongation index (Table 1). Proportions of 18:0 and elongation index in the crossbreds $\left(\mathrm{F}_{1}\right)$ were higher than the average of Jersey and Limousin purebreds (Table 3). On the other hand, proportions of 16:0 and SFA were below the means of the purebred calves. Table 3 also shows that the USR and PSR ratios were the same in both the $F_{1}$ and Jersey calves.

Estimates of genetic effects (Table 4) portray a significant effect of sire breed on 16:0, $18: 0,18: 1 \mathrm{n}-9$, SFA and desaturation and elongation indices. This implies a direct additive 
Table 2. Sex differences in phospholipid fatty acids $(\mathrm{LSM} \pm \mathrm{SE}$ ) in young calves (percentage total fatty acids) ${ }^{\mathrm{Z}}$

\begin{tabular}{|c|c|c|c|}
\hline Fatty acids & $\begin{array}{l}\text { Heifer calves } \\
\quad(\mathrm{n}=38)\end{array}$ & $\begin{array}{l}\text { Steer calves } \\
\quad(\mathrm{n}=58)\end{array}$ & Significance \\
\hline $14: 0$ & $2.6 \pm 0.5$ & $3.7 \pm 0.4$ & $*$ \\
\hline $14: 1$ & $0.6 \pm 0.2$ & $0.9 \pm 0.2$ & $*$ \\
\hline 16DMA & $4.9 \pm 0.5$ & $3.4 \pm 0.5$ & $* *$ \\
\hline $18: 2$ & $10.7 \pm 0.4$ & $11.2 \pm 0.3$ & $*$ \\
\hline $20: 3$ & $0.1 \pm 0.1$ & $0.4 \pm 0.1$ & $* *$ \\
\hline
\end{tabular}

Table 3. Breed differences in phospholipid fatty acids $(\mathrm{LSM} \pm \mathrm{SE})$ in young calves (percentage total fatty acids $)^{\mathrm{A}}$

\begin{tabular}{|lccc|}
\hline Fatty acid & $\begin{array}{c}\text { Jersey } \\
(\mathrm{n}=18)\end{array}$ & $\begin{array}{c}\text { Limousin } \\
(\mathrm{n}=26)\end{array}$ & $\begin{array}{c}\mathrm{F}_{\mathrm{J}} \mathrm{J} \times \mathrm{L} \\
(\mathrm{n}=52)\end{array}$ \\
\hline $16: 0$ & $20.2 \pm 1.1^{\mathrm{ab}}$ & $22.6 \pm 1.0^{\mathrm{a}}$ & $18.9 \pm 0.6^{\mathrm{b}}$ \\
$18: 0$ & $11.2 \pm 0.4^{\mathrm{a}}$ & $11.9 \pm 0.4^{\mathrm{ab}}$ & $12.4 \pm 0.2^{\mathrm{b}}$ \\
$24: 0$ & $0.5 \pm 0.3^{\mathrm{a}}$ & $1.6 \pm 0.3^{\mathrm{b}}$ & $1.2 \pm 0.2^{\mathrm{b}}$ \\
SFA & $41.8 \pm 1.3^{\mathrm{a}}$ & $45.8 \pm 1.3^{\mathrm{b}}$ & $42.1 \pm 0.8^{\mathrm{a}}$ \\
USR & $1.4 \pm 0.07^{\mathrm{a}}$ & $1.3 \pm 0.07^{\mathrm{b}}$ & $1.4 \pm 0.05^{\mathrm{a}}$ \\
PSR & $0.7 \pm 0.05^{\mathrm{a}}$ & $0.6 \pm 0.05^{\mathrm{b}}$ & $0.7 \pm 0.03^{\mathrm{a}}$ \\
Elongation index & $61.2 \pm 1.2^{\mathrm{a}}$ & $57.7 \pm 1.2^{\mathrm{b}}$ & $62.4 \pm 0.7^{\mathrm{a}}$ \\
${ }^{\mathrm{A}}$ Row means with different superscripts significantly differ $(\mathrm{p}<0.05)$ & \\
\hline
\end{tabular}

ADULI et al. 1998b). The mating of these two breeds to produce reciprocal $F_{1}$ calves presents an ideal model for studying the mode of inheritance of fatty acids. In order to eliminate age variation, purebred Jersey and Limousin calves of the same age (9-10 months), within the same herd as the $\mathrm{F}_{1} \mathrm{~s}$ were produced for making comparisons.

\section{Sex differences}

There were significant differences between the sexes. Steer calves had higher proportions of 14:0, 14:1, 18:2, 20:3 and less 16 DMA than heifer calves (Table 2). Fatty acids can be elongated by a mitochondrial system which uses acetyl-coA as the unit for two-carbon addition and NADPH for reduction. In general, the mitochondrial system elongates fatty acids in the range $\mathrm{C} 10$ to $\mathrm{C} 14$, whereas the microsomal system uses $\mathrm{C} 16$ and longer fatty acids (GUNSTONE et al. 1986). Thus, 14:0 (myristate) and 14:1 (myristoleate) are both synthesized de novo by enzymatic processes of chain elongation and desaturation, respectively, in the liver of mammals (FISCHER 1989). Polyunsaturated fatty acids (18:2 and 20:3) are not synthesized de novo. As pointed out in previous studies (SCOTT and AsHes 1993; VAN OECKEL et al. 1996; ALASNIER and GANDEMER 1998), 18:2 is an essential fatty acid 
that has a dietary origin and is a metabolite for another long-chain PUFA - arachidonate (20:4). Di-homo-gamma linolenate $(20: 3)$ is also a precursor for the synthesis of $20: 4$ and this conversion is brought about by the $\Delta^{5}$-desaturase enzyme (SimOpOUlous 1994).

The results suggest that the differences between steer and heifer calves in $14: 0$ and $14: 1$ are linked to enzymatic processes in which hormonal influences are evident. The fact that heifer calves are expected to contain the sex-limited hormone oestrogen, and steer calves testosterone, presents a major source of hormonal variation between the sexes. However, the differences in 18:2 and 20:3 between steers and heifers are more likely to be associated with variation in dietary consumption, absorption and utilization of feeds. Furthermore, steer calves could have a higher activity of $\Delta^{5}$-desaturase enzyme than heifer calves, or its activity in the muscle tissue continues for longer periods in steers than heifers.

The sex differences observed in this study are consistent with other reports in the literature (WALDMAN et al. 1968; TERREL et al. 1969; MARCHELlO et al. 1970), but in contrast to those that found the percentages of $14: 0,14: 1,16: 1$ and $20: 5$ of intramuscular phospholipids to be higher in heifers than steers (HORNSTEIN et al. 1961; LARICK et al. 1989; ZEMBAYASHI et al. 1995). Reports of sex differences in fatty acid composition in the literature are not consistent, largely due to the confounding effects of age, dietary regime (HUERTA-LEINDENZ et al. 1996) and anatomical site of sampling (WESTERLING and HEDRICK, 1979). However, the results in this section are consistent with those of yearling steers and heifers (MAlau-Aduli et al. 1998b).

\section{Breed differences}

Even at a young age of 9-10 months, significant differences in the fatty acid composition of muscle phospholipids were detected between Jersey, Limousin and reciprocal $\mathrm{F}_{1}$ Jersey $\times$ Limousin calves (Table 1). Limousin calves contained the highest proportions of individual SFA 16:0, 24:0 and total SFA (Table 3). This observation agrees with previous results in the triacylglycerol (MALAU-ADULI et al. 1995, 1996, 1997a; SIEBERT et al. 1998) and phospholipid (MALAU-ADUli et al. 1997b, 1998b; DELAND et al. 1998) fractions which showed that Limousin cattle contain more SFA than Jersey cattle of the same age within the same herd.

There is evidence to suggest that different breeds of cattle begin to deposit intramuscular fat at different rates due to variation in maturity patterns. For instance, CRAMER et al. (1973) collected muscle biopsy samples from the biceps femoris muscles of Hereford, Angus and Holstein steers and heifers every 56 days from 28 days of age to slaughter ( 24 months). Fat content of biopsy samples was determined and results plotted as a function of growth. Herefords and Holsteins begin to deposit intramuscular fat at an accelerated rate at 15 months, whereas Angus increased the rate of deposition at about 9 months. In this study, Jersey breeds are early-maturing whereas Limousins are late-maturing. Jerseys deposit intramuscular fat earlier than Limousins (CUNDIFF et al. 1988), hence a dilution of their saturated fatty acids by unsaturates would occur earlier than in Limousins. Thus, at the same age, Jerseys would still have less saturates than Limousins. The differences observed in $20: 4$, SFA, PSR and elongation index between the breeds was not consistent in steers and heifers since the interaction between sex and breed was significant (Table 1).

Crossbreeding Jersey and Limousin breeds resulted in an elevation of the proportions of 18:0 and elongation index in the phospholipid fraction of $F_{1}$ crossbred animals (Table 3). Furthermore, there was a decrease in the proportions of 16:0 and total SFA in the $F_{1}$ animals, consistent with previous observations in the adipose tissue (MALAU-ADULI et al. 1998a). Given that elongation index also increased in the $F_{1}$ animals, it is expected that there would be an increase in the chain lengthening of fatty acids to the long-chain PUFAs that characterize the phospholipids of cell membranes.

\section{Heterosis}

Crossbred animals had higher means than the average of purebreds in the proportions of 18:0 and the elongation index (Table 3). Heterosis is expressed as the difference between 
Table 4. Estimates of genetic effects in muscle phospholipid fatty acids expressed as deviation between means $(\%)^{\mathrm{Z}}$

\begin{tabular}{|c|c|c|c|}
\hline Fatty acid & $\begin{array}{l}\text { Sire breed }^{\mathrm{A}} \\
\text { (Additive) }\end{array}$ & $\begin{array}{c}\text { Dam breed } \\
\text { (Maternal+additive) }\end{array}$ & $\begin{array}{c}\text { Heterosis }{ }^{\mathrm{C}} \\
\text { (Dominance) }\end{array}$ \\
\hline $16: 0$ & $-2.6 *$ & -0.8 & $-3.4^{* *}$ \\
\hline $18: 0$ & $-0.6 \%$ & -0.1 & $0.8 *$ \\
\hline $18: 1 n-9$ & $1.7^{*}$ & 0.1 & -0.2 \\
\hline $18: 2$ & -0.5 & $0.9 *$ & 0.3 \\
\hline $20: 3$ & 0.1 & $-0.4 * *$ & 0.1 \\
\hline $20: 4$ & 0.1 & $0.9^{* *}$ & 0.3 \\
\hline $24: 0$ & -0.5 & $-0.7 *$ & 0.2 \\
\hline SFA & $-3.7 * *$ & $-1.7^{*}$ & $-2.7 *$ \\
\hline Desat. (C18) & $2.7 *$ & -0.1 & -1.7 \\
\hline Elongation index & $3.9 * *$ & $1.1 *$ & $4.3 * \%$ \\
\hline \multicolumn{4}{|c|}{$\begin{array}{l}{ }^{\mathrm{z}} \text { Only traits that significantly differed presented } \\
{ }^{\mathrm{A}}((\text { Jersey sire }- \text { Limousin sire }) /(\text { Limousin sire })) \times 100 \\
{ }^{\mathrm{B}}((\text { Jersey dam }- \text { Limousin dam }) /(\text { Limousin dam })) \times 100 \\
{ }^{\mathrm{C}}((\text { Crossbred }- \text { Parental }) /(\text { Parental })) \times 100\end{array}$} \\
\hline
\end{tabular}

the crossbreds and parental breed means (FALCONER 1993). This example of heterosis demonstrates the dominance of a gene (or genes) of one breed over the other for these traits. The significant effect of heterosis in the proportions of 16:0,18:0, SFA and elongation index is portrayed in Table 4. Although it is difficult to say how many genes are involved, Table 4 clearly demonstrates significant dominance effect in the proportions of these fatty acids. The key point is that heterosis decreased the proportions of SFA and by default, the proportions of unsaturated fatty acids are expected to increase. This is in line with the effect of increased fatness associated with the increase in unsaturated fatty acids previously demonstrated by SiEBerT et al. (1996) and MALAu-Aduli et al. (1998c).

An important measure of genetic variance is additive genetic effect because it is the major heritable component and hence the chief cause of resemblance between relatives. Significant additive genetic effects were observed in the proportions of $16: 0,18: 0,18: 1 \mathrm{n}-9$, SFA and desaturation and elongation indices (Table 4). A similar observation was evident in the adipose tissue for $14: 0,16: 0,18: 1 \mathrm{n}-7$ and SFA (MALAU-ADULI et al. 1998a). The implication is that on the average, sires would pass their genes for these traits to their offspring in the next generation since they are considered heritable. Thus, by preventing sires with high proportions of $16: 0$ and total SFA, beef cattle breeders can genetically select against these fatty acids, not in terms of human health implications, but with regard to the physiological significance of metabolic processes associated with growth and reproductive functions in cell membranes.

During gamete formation, sires and dams contribute $50 \%$ each of their genes to offspring, hence the maternal effect is of genetic significance. The effect of dam estimates a combination of both additive and maternal effects, and these were significant in the proportions of $18: 2$, $20: 3,20: 4$, SFA and elongation index (Table 4). It is not easy to accurately separate the additive from maternal effects in this experimental design of single crossing. A backcross experimental design would ensure complete segregation of the genes, hence a better separation of both components.

It is interesting that the individual fatty acids showing significant combined effects of maternal and additive effects are all long-chain PUFA (Table 4). The fact that sire effect on these fatty acids $(18: 2,20: 3$ and 20:4) was not significant almost exclusively attributes the difference to maternal effect since the additive component is negligible. Given the dietary 
origin of $18: 2$ which in turn serves as a metabolite for the synthesis of $20: 4$, the implication is that the mothering abilities between dams significantly differed. The key point is that proportions of PUFA in the muscle would have a low heritability since the contribution of additive genetic variance is negligible.

In conclusion, significant sex and breed variations were observed in fatty acids of muscle phospholipids at 9 months of age. Individual fatty acids 16:0,18:0,18:1n-9 and desaturation and elongation indices are likely to be heritable, whereas PUFAs 18:2, 20:3 and $20: 4$ are not. In addition, heterosis can be exploited as a tool for genetically lowering the proportion of 16:0 and total SFA. This may be of physiological significance in the phospholipids of cell membranes and metabolic processes associated with growth and reproductive functions.

\section{Acknowledgements}

This study was funded by the J.S. Davies Bequest Fund to the University of Adelaide, the South Australian Cattle Compensation Trust Fund and the Australian Development Cooperation Scholarship from AusAID for A.E.O.M.-A.

\section{References}

Alasnier, C.; GAndemer, G., 1998: Meat Sci. 48, 225.

Cramer, D. A.; Hecker, A. L.; Cornforth, D. P., 1973: Intramuscular fat deposition in cattle. In: Proc. Western Section, American Soc. Anim. Sci., Vol. 24, p. 95.

Cundiff, L. V.; Dikeman, M. E.; Koch, R. M.; Crouse, J. D.; Gregory, K. E., 1988: Breeding for Lean Beef. Beef Research Progress Report No. 3, USDA, pp. 3-7.

Deland, M. P. B.; Malau-Aduli, A. E. O.; Siebert, B. D.; Bottema, C. D. K.; Pitchford, W. S., 1998: Sex and breed differences in the fatty acid composition of muscle phospholipids in crossbred cattle. In: Proc. 6th World Congress Genetics Applied to Livestock Production, Vol. 25, p. 185.

FALCONER, D. S., 1993: Introduction to Quantitative Genetics, 3rd edn. Longman Scientific and Technical, Harlow, UK. 438 pp.

FISCHER, S., 1989: Adv. in Lipid Res. 23, 169.

Gunstone, F. D.; Harwood, J. L.; Padley, F. B., 1986: The Lipid Handbook. Chapman and Hall, London. 525 pp.

Hornstein, P. E.; Crowe, P. F.; Heimberg, M. J., 1961: J. Food Sci. 26, 581.

Huerta-Leidenz, N. O.; Cross, H. R.; Savell, J. W.; Lunt, D. K.; Baker, J. F.; Smith, S. B., 1996: J. Anim. Sci. 74, 1256.

Larick, D. K.; Turner, B. E.; Koch, R. M.; Crouse, J. D., 1989: J. Food Sci. 54, 521.

Malau-Aduli, A. E. O.; Siebert, B. D.; Pitchford, W. S.; BotTema, C. D. K., 1995: Proc. Aust. Assoc. Anim. Breed. Genet. 11, 554.

Malau-Aduli, A. E. O.; Siebert, B. D.; Bottema, C. D. K.; Pitchford, W. S., 1996: Genetic comparison of the fatty acid composition of intramuscular and adipose tissue lipids from early and late maturing beef cattle. In: Proc. Asian-Australasian Association of Animal Production, Tokyo, Japan, Vol. 2, p. 32.

Malau-Aduli, A. E. O.; Siebert, B. D.; Bottema, C. D. K.; Pitchford, W. S., 1997a: Aust. J. Agric. Res. 48, 715.

Malau-Aduli, A. E. O.; Siebert, B. D.; Bottema, C. D. K.; Pitchford, W. S., 1997b: Genotype and site differences in the fatty acid composition of muscle phospholipids in cattle. In: Proc. Association for the Advancement of Animal Breeding and Genetics, Dubbo, Australia, Vol. 12, p. 580.

Malau-Aduli, A. E. O.; Siebert, B. D.; BotTema, C. D. K.; Pitchford, W. S., 1998a: Mode of inheritance of triacylglycerol fatty acids in beef adipose tissue. In: Proc. American Society of Animal Science/American Dairy Science Joint Meeting, Denver, Colorado (J. Anim. Sci. 76, Suppl. 1 Abstracts).

Malau-Aduli, A. E. O.; Siebert, B. D.; Bottema, C. D. K.; Pitchford, W. S., 1998b: J. Anim. Sci. 76, 766.

Malau-Aduli, A. E. O.; Siebert, B. D.; Bottema, C. D. K.; Pitchford, W. S., 1998c: Genetic and 
phenotypic correlations between triacylglycerol fatty acids at weaning and slaughter in beef cattle. In: Proc. 49th European Association of Animal Production, Warsaw, Poland, GC 3.5/16.

Marchello, J. A.; Vavra, M.; Dryden, F. D.; Ray, D. E., 1970: J. Anim. Sci. 31, 707.

MilleR, G. J.; FIELD, R. A.; RILEY, M. L., 1986: J. Food Quality 9, 331.

O’Keefe, P. W.; Wellington, G. H.; Mattick, L. R.; STOUGgER, J. R., 1968: J. Food Sci. 33, 188.

Romans, J. R.; Norton, H. W.; Palmer, I. S.; Wenger, D. R.; Costello, W. J.; Tuma, H. J.; Ball, R.; Wahlstrom, R. C., 1974: J. Anim. Sci. 38, 38.

Rule, D. C.; Smith, S. B.; Romans, J. R., 1995: Fatty acid composition of muscle and adipose tissue of meat animals. In: SMITH, S. B.; SMITH, D. R., (eds), Current Advances in the Biology of Fat in Meat Animals. American Society of Animal Science, Champaign, Illinois. pp. 144-165.

SAS INSTITUTE, INC. 1989: SAS User’s Guide: Statistics. Version 5.04, SAS Institute, Inc., Cary, NC. SCOTT, T. W.; AsheS, J. R., 1993: Aust. J. Agric. Res. 44, 495.

Siebert, B. D.; Deland, M. P.; Pitchford, W. S., 1996: Aust. J. Agric. Res. 47, 943.

Siebert, B. D.; Malau-Aduli, A. E. O.; Bottema, C. D. K.; Deland, M. P. B.; Pitchford, W. S., 1998: Genetic variation between crossbred weaner calves in triacylglycerol fatty acid composition. In: Proceedings 6th World Congress Genetics Applied to Livestock Production, Vol. 25, p. 177.

Simopoulous, A. P., 1994: Nutrition Today (Jan/Feb), 12.

Terrel, R. N.; Suess, G. C.; Bray, R. W., 1969: J. Anim. Sci. 28, 449.

van Oeckel, M. J.; Casteels, M.; Warnants, N.; van Damme, L.; Boucque, C. V., 1996: Meat Sci. $44,55$.

Waldman, R. C.; Suess, G. G.; Brungardt, V. H., 1968: J. Anim. Sci. 27, 632.

Westerling, D. B.; Hedrick, H. B., 1979: J. Anim. Sci. 48, 1343.

Zembayashi, M.; Nishimura, K.; LunT, D. K.; Smith, S. B., 1995: J. Anim. Sci. 73, 3325.

Authors' addresses: A. E. O. Malau-Aduli (for correspondence), National Animal Production Research Institute, Ahmadu Bello University, P.M.B. 1096 Zaria, Nigeria; B. D. Siebert, C. D. K. Bottema and W. S. Pitchford, Department of Animal Science, University of Adelaide, Waite Agricultural Research Institute, Glen Osmond SA 5064, Australia 